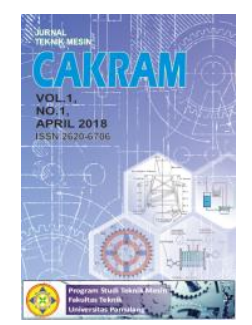

\title{
ANALISA KERUSAKAN RISER TUBE PADA MESIN LPDC DAN UPAYA PENCEGAHANNYA
}

\author{
Giyanto $^{1}$ \\ ${ }^{1}$ Program Studi Teknik Mesin, Universitas Pamulang, Jl. Surya Kencana No. 1, Tangerang Selatan, Indonesia \\ E-mail : giyanto_328@yahoo.co.id
}

Masuk : 5 Maret $2018 \quad$ Direvisi :29 September $2018 \quad$ Disetujui : 5 Oktober 2018

\begin{abstract}
Abstrak : Riser tube pada mesin LPDC penggantian setiap 10 × 8 jam ( 80 Jam ). Kerusakan yang terjadi pada umumnya retak dan keropos pada permukaan body Riser Tube. Akibat kerusakan tersebut cairan laju kuningan yang masuk ke cetakan tumpah ke lokasi sekitar mesin. Tujuan penelitian kerusakan Riser Tube adalah untuk menganalisa penyebab terjadinya kerusakan retak dan keropos serta upaya memperpanjang umur pakai. Analisa pengkajian penyebab utama terjadinya kerusakan Riser Tube dilakukan melalui pengujian komposisi kimia, Uji kekerasan, Uji scanning elektron microscopy ( SEM ), Uji metalografi dan pengamatan perubahan sifat mekanis logam material Riser Tube akibat pengaruh panas pada proses peleburan di tungku furnace. Kesimpulan penyebab utama retak dan keropos disebabkan thermal fatique dan korosi suhu tinggi. Digunakan untuk pengembangan kualitas serta optimasi usaha memperpanjang umur operasional ( Life time ) meliputi perbaikan desain, material, manufaktur, cara pemasangan serta penerapan system manajemen pemeliharaan yang tepat.
\end{abstract}

Kata kunci: $L P D C$, Riser Tube, Kerusakan, Pengujian, Pemeliharaan.

Abstract: Riser tube on LPDC replacement machine every $10 \times 8$ hours (80 hours). The damage that occurs is generally cracked and porous on the surface of the Riser Tube body. As a result of the damage the brass rate fluid that goes into the mold spills into the location around the machine. The objective of this research is to analyze the cause of crack and porous damage and to extend the life of the wearer. Assessment analysis of the main causes of damage to Riser Tube is done through testing of chemical composition, Hardness Test, Scanning Electron Microscopy (SEM) Test, Metallographic Testing, and Observation of Changes in Mechanical Properties of Riser Tube Metal Material due to heat effect on melting process in Furnace. The main causes of crack and porous causes are due to thermal fatique and high temperature corrosion. Used for the development of Riser Tube quality as well as business optimization to extend operational life (Life time) covering the design, material, manufacturing, installation and maintenance of appropriate maintenance management system.

Keyword : LPDC, Riser Tube, Damage, Examination, Maintenance.

\section{PENDAHULUAN}

Mesin Low Pressure Die Casting (LPDC) merupakan jenis die casting yang menggunakan tekanan rendah dalam proses manufaktur pengecoran sehingga menghasilkan produk kwalitas tinggi untuk part - part material non ferrous dengan paduan (alloy) aluminium (al), seng (zinc), tembaga (copper) dan kuningan (brass). Saat ini Mesin LPDC digunakan untuk proses produksi pengecoran kuningan (bras casting) .

Operasional Mesin LPDC pada temperatur $\pm 1.000^{\circ} \mathrm{C}$, Untuk mengendalikan kinerja mesin pada temperatur tersebut, dibutuhkan kontrol suhu pada tungku furnace material panas agar di ketahui standart optimal proses peleburan kuningan (brass casting) yang terdiri dari paduan Tembaga $(\boldsymbol{C u})$ dan Zing $(\boldsymbol{Z n})$. Kontrol suhu tungku furnace diidentifikasi oleh Thermocouple yang ditempatkan pada lubang bagian dalam Thermal shield dan terpasang pada penutup tungku furnace (furnace cover). Sebagian body Riser Tube (bagian tengah ke bawah) terendam material panas pada temperatur tinggi dan bagian kepala (tengah keatas) berada pada temperatur ruang / suhu bebas. Masuknya material ke mould atau cetakan dari tungku furnace yang melalui lubang aliran material di identifikasi oleh Riser Tube yang terpasang pada penutup tungku furnace (furnace cover). Tujuan penelitian kerusakan Riser 
Tube adalah untuk menganalisa penyebab terjadinya kerusakan retak dan keropos. Pengujian dilakukan melalui uji komposisi kimia, uji metalografi, uji kekerasan dan uji SEM / EDS.
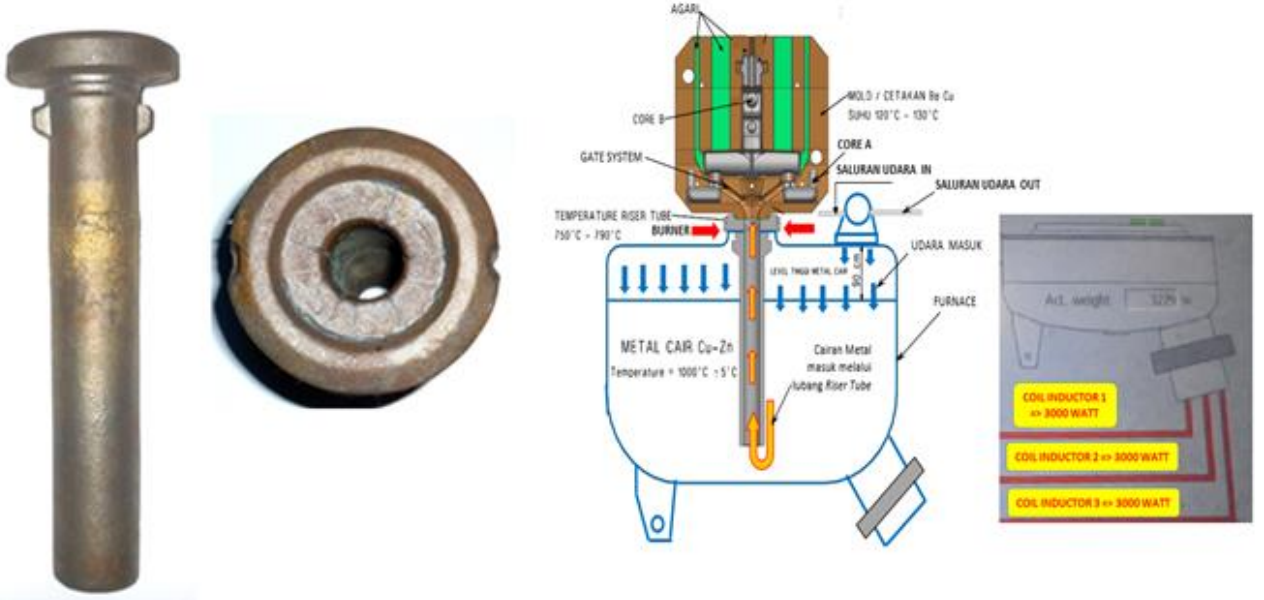

Gambar 1. Sample uji pada riser tube dan skema proses LPDC

\section{METODOLOGI}

a.Tahap awal penelitian

Pada tahap ini akan dilakukan review terhadap Riser Tube yang meliputi analisis kegagalan cacat retak dan keropos, analisa komposisi kimia, analisa metalografi dan analisa SEM / EDS .

\section{b.Tahap penelitian}

Pengamatan visual yaitu dengan melakukan pemeriksaan secara langsung terhadap material Riser Tube yang mengalami kerusakan dan kegagalan. Untuk mendapatkan data yang lebih akurat dilakukan pengambilan photo pada Riser Tube yang rusak dan komponen-komponen lainnya yang berhubungan dengan sistem operasi Mesin LPDC

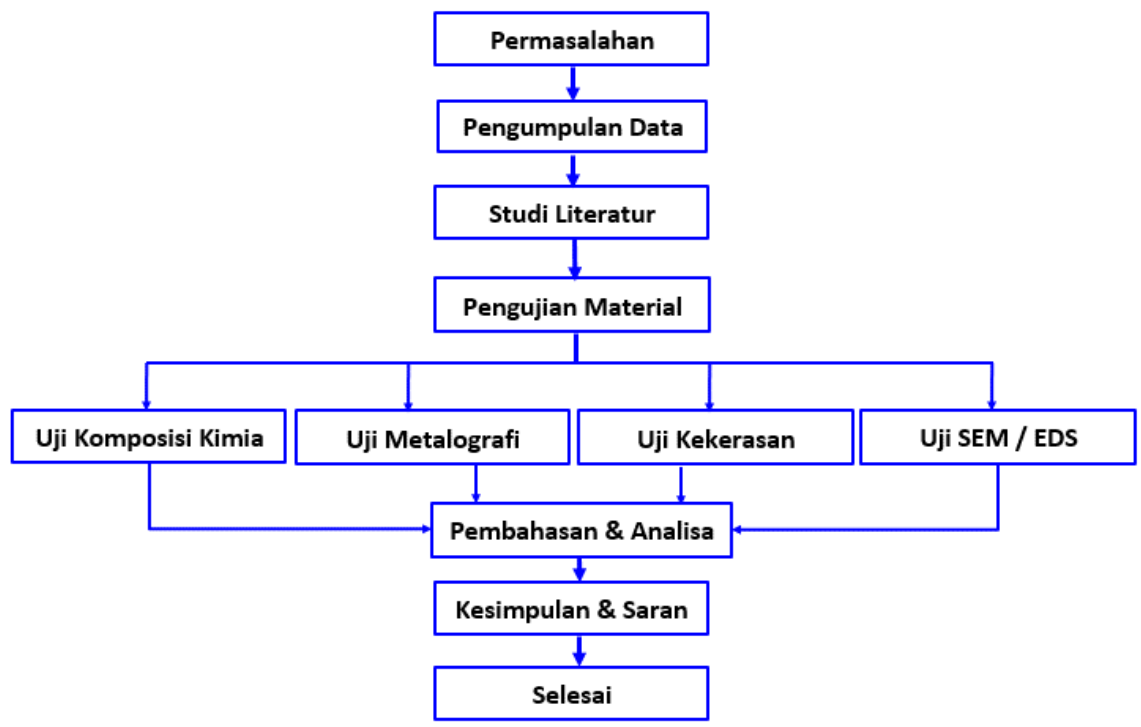

Gambar 2. Diagram alir penelitian 


\section{c. Pengujian Komposisi Kimia}

Pemeriksaan komposisi kimia bertujuan untuk mengetahui komposisi material Riser Tube sehingga dapat dilakukan komparasi antara material desain dengan komposisi material Riser Tube secara aktual.

\section{d. Pengamatan Visual / Makrografi}

Pengamatan visual yaitu dengan melakukan pemeriksaan secara langsung terhadap material Riser Tube yang mengalami kerusakan dan kegagalan. Untuk mendapatkan data yang lebih akurat dilakukan pengambilan photo pada Riser Tube yang rusak.

\section{e. Pengujian Kekerasan}

Uji kekerasan (hardness testing) dimaksudkan untuk mengetahui daya tahan Riser Tube terhadap deformasi plastis, ketahanan aus serta abrasif pada material.

\section{f. Analisa Scanning Electron Microscopy (SEM)}

Pada analisa SEM dan EDX, dilakukan pada permukaan yang mengalami retak, hal ini dimaksudkan untuk memastikan salah satu penyebab terjadinya retak pada permukaan Riser Tube.

\section{HASIL \& PEMBAHASAN}

Proses pengecoran mesin LPDC, logam cair kuningan setelah dilebur didalam tungku furnace kemudian dialirkan menuju cetakan melalui Riser Tube, untuk menekan laju cairan tersebut diperlukan tekanan rendah dibawah satu atmosfer sehingga tekanan terjadi pada permukaan logam . Logam akan terdorong ke atas melalui lubang Riser Tube dan masuk ke dalam cetakan atau mould yang telah dipasang sebelah atas dan menghasilkan produk coran.

\section{a. Analisa Struktur Mikro Riser Tube}

Analisa struktur mikro dilakukan untuk mengetahui adanya unsur cacat material, perubahanan struktur material
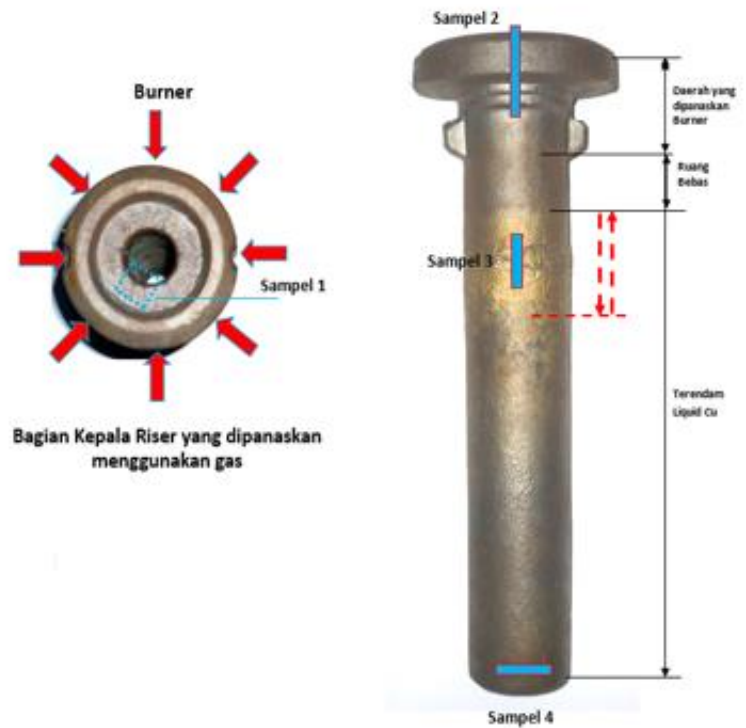

Sampel 1. Potongan sejajar retak pada lubang riser tube

Sampel 2. Potongan memanjang dilokasi burner

Sampel 3. Potongan memanjang dilokasi cacat

Sampel 4. Potongan melintang bagian yang terendam liquid

Gambar 3. Lokasi pengambilan sampel 

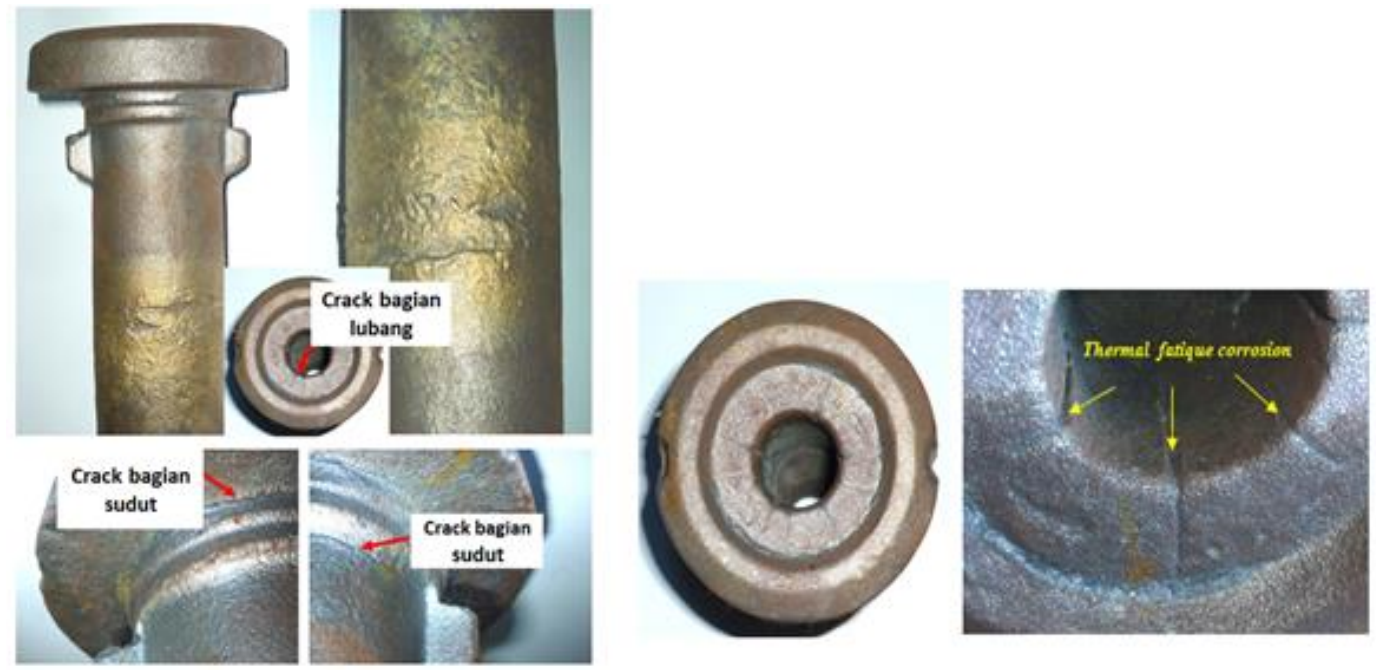

Gambar 4. Indikasi cacat retak bagian lubang dan retak bagian sudut dan Bentuk cacat thermal fatique corrosion yang terdapat pada Riser Tube.

Indikasi cacat yang terdapat pada riser tube antara lain :

- $\quad$ Terkikis permukaan akibat fluktuasi liquid produk

- $\quad$ Retak didaerah sudut sejajar cacat permukaan menunjukkan adanya beban dinamis.

- $\quad$ Retak - retak pada bagian lubang alir liquid akibat proses pemanasan burner

Bentuk cacat thermal fatique corrosion pada bagian kepala Riser Tube yang di akibatkan terkena panas dari tungku barner dan cairan brass casting masuk ke dalam bagian yang retak .
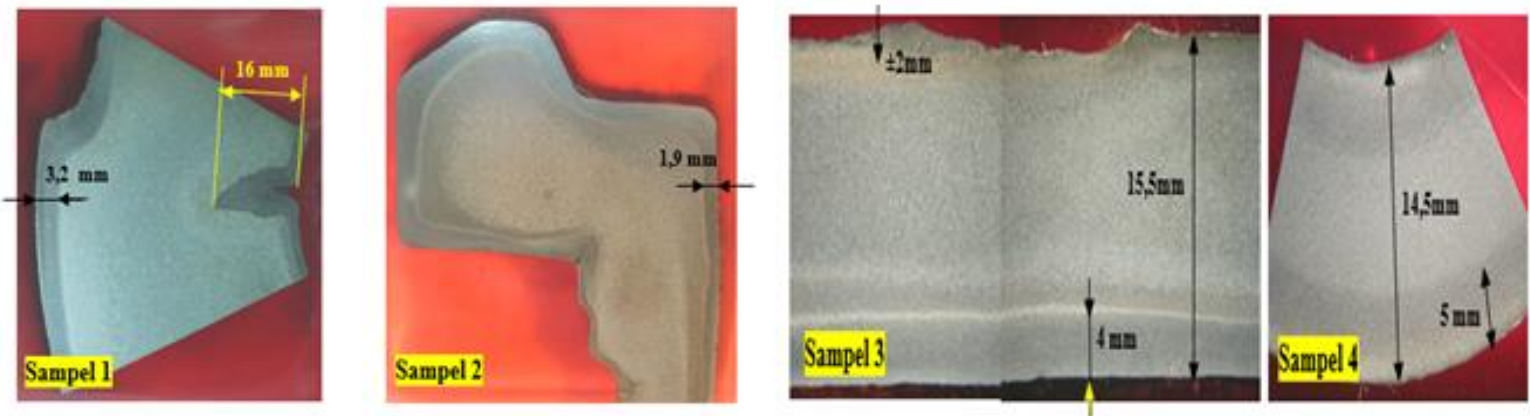

Gambar 5. Sampel 1 potongan melintang dan sampel 2 potongan memanjang dan Sampel 3 Potongan memanjang dibagian cacat mempunyai dekarburisasi dan permukaan bagian kepala riser tube

Pada Sampel 1 potongan melintang dan sampel 2 potongan memanjang yang diambil di bagian kepala Riser Tube, tebal dekarburisasi $1.9 \mathrm{~s} / \mathrm{d}$ 3,2 $\mathrm{mm}$ sedangkan kedalaman thermal crack $16 \mathrm{~mm}$
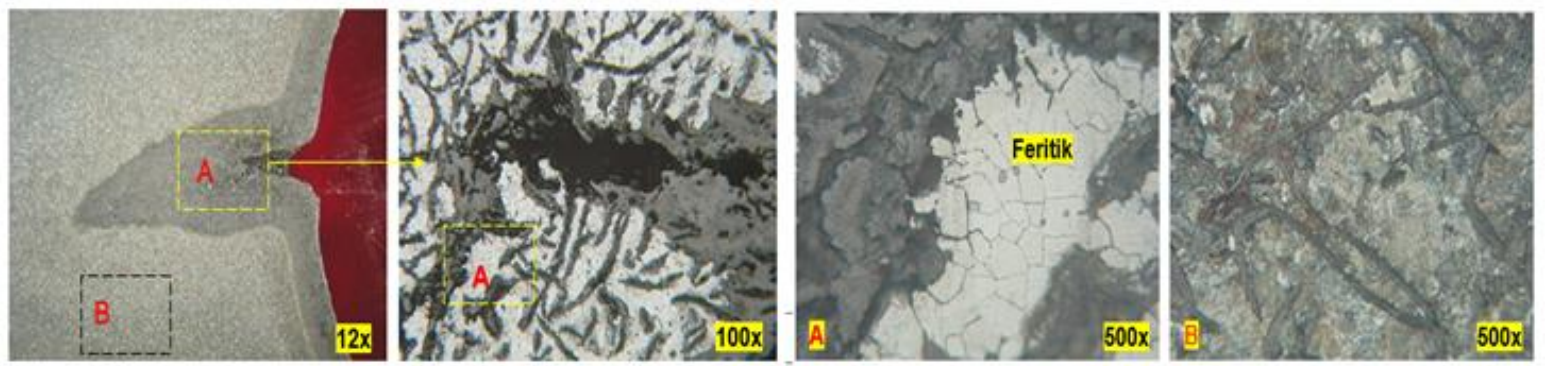
Permukaan bagian kepala riser tube mengalami dekarburisasi atau pengurangan carbon akibat cairan brass casting masuk ke dalam bagian yang retak. Pembesaran dari lokasi A yang mengalami dekarburisasi, struktur mikro berupa feritik dan pembesaran pada lokasi B matriks srtuktur berupa perlitik dengan grafit lamelar.
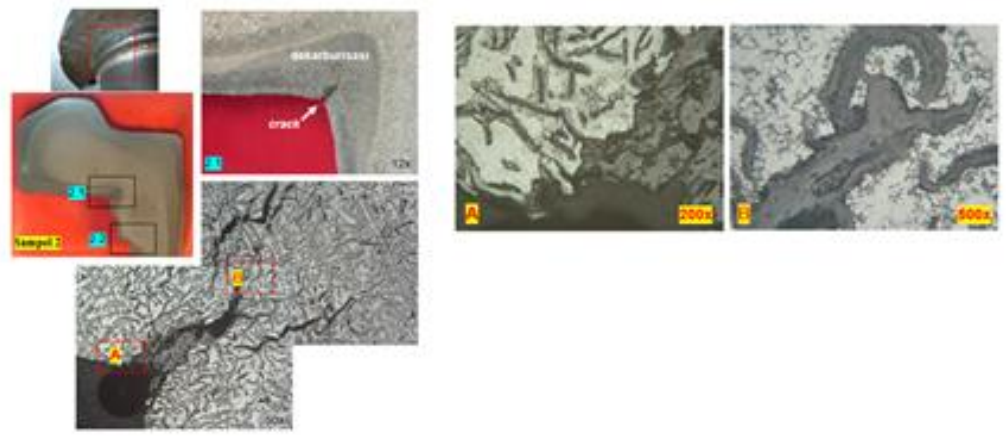

Gambar 7. Sampel 2 potongan memanjang kepala Riser Tube mengalami dekarburisasi.

Sampel 2 potongan memanjang lokasi 2.1 pada permukaan bagian kepala Riser Tube mengalami dekarburisasi $3.2 \mathrm{~mm}$, akibat pemanasan burner lebih tebal dibanding sisi lubang Riser Tube dengan yang dilalui produk $1.9 \mathrm{~mm}$ (lihat keterangan Gambar 8). Retak memotong batas butir (Transgrannular Crackings) terjadi di daerah sudut yang mengalami SCC (Stress Corrosion Crackings). Korosi dapat terjadi dari kandungan bahan bakar gas.

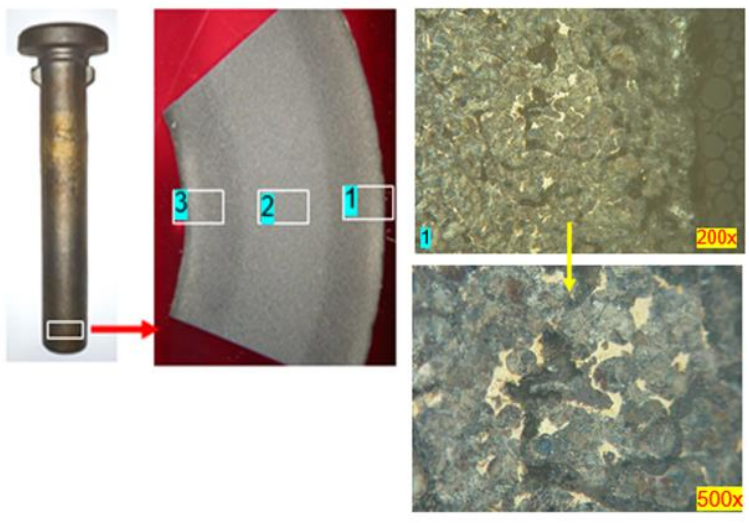

Gambar 8. Pemeriksaan sampel 4 daerah yang terendam liquid $\mathrm{Cu}$ pada bagian luar atau bagian diameter luar.
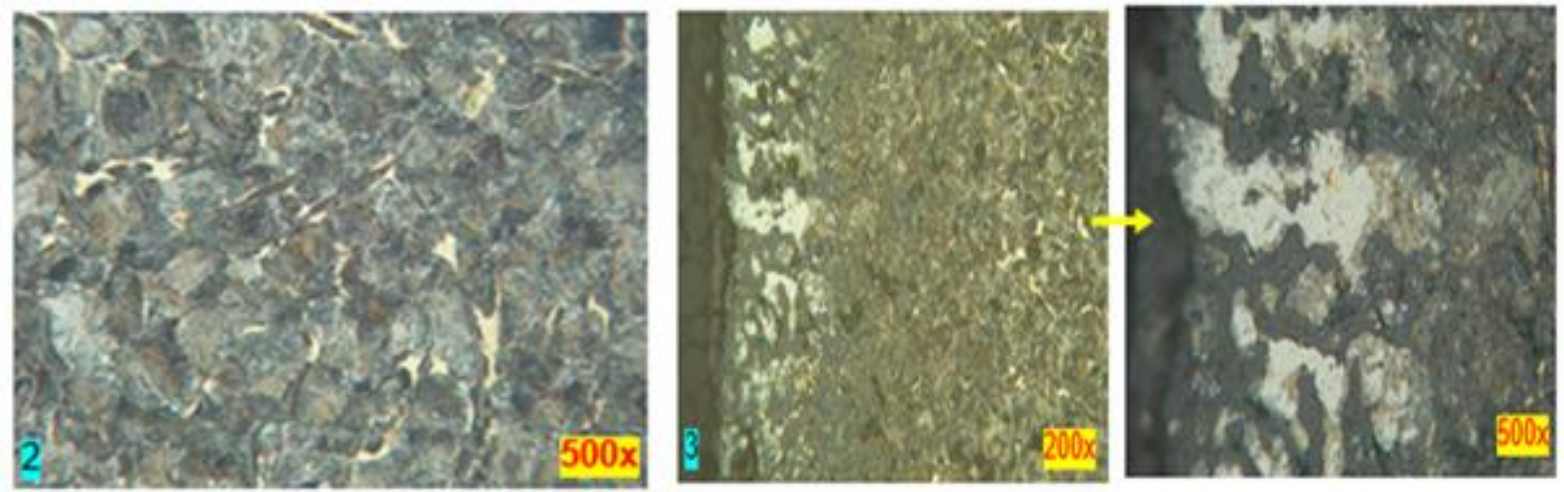

Gambar 9. Pemeriksaan sampel 4 daerah yang terendam liquid $\mathrm{Cu}$ pada bagian tengah dan pemeriksaan sampel 4 daerah yang terendam liquid $\mathrm{Cu}$ pada bagian dalam atau bagian diameter dalam 
Pada gambar 8,9 menjelaskan pemeriksaan sampel 4 merupakan daerah yang terendam liquid $\mathrm{Cu}$ secara terus menerus sehingga material $\mathrm{Cu}$ masuk ketengah tebal. Struktur mikro bagian tengah berupa perlitik dan $\alpha \mathrm{Cu} / \mathrm{brass}$

b. Analisa Scanning Electron Microscopy (SEM) dan Energy Dispersive X-Ray Analysis (EDX)

Pada analisa SEM dan EDX, dilakukan pada permukaan yang mengalami retak permukaan Riser Tube

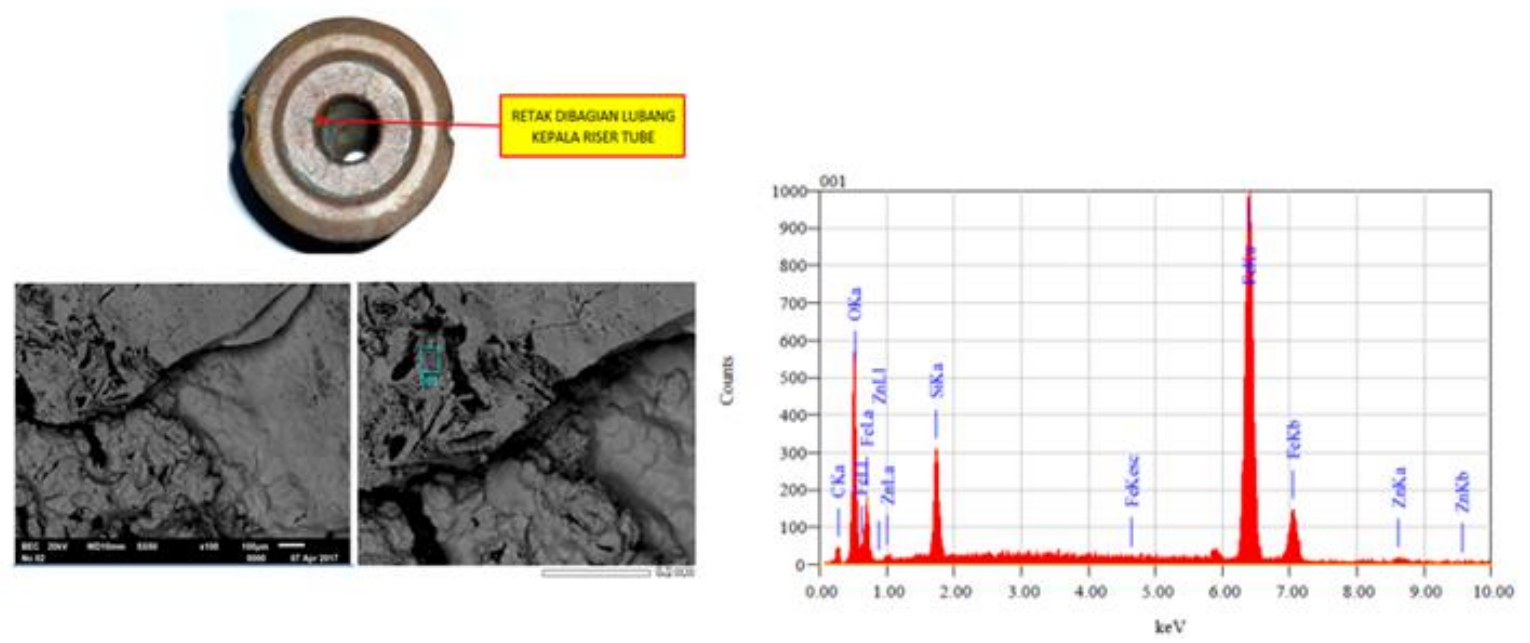

Gambar 10. Pemeriksaan permukaan kepala riser tube pada lokasi yang retak dengan 100x pembesaran menggunakan SEM

Dari hasil uji SEM menggambarkan bahwa unsur kimia Zn dan detail terhubungkan yang terbentuk pada Rz max, proses retak dan keropos. Kerusakan kombinasi dari thermal fatique dan retak dengan liquid metal embrittlement (LME) dibuktikan dari hasil uji SEM

ZAF method standardless quantitative analysis

Fitting coefficient : 0.2179

Tabel hasil uji EDX unsur kimia Zn dengan mass 2.07\%, atom 0.99\% dan K 1.9257

\begin{tabular}{|c|c|c|c|c|c|c|c|c|}
\hline Element & $($ Kev $)$ & Mass \% & $\begin{array}{c}\text { Error } \\
\%\end{array}$ & Atom \% & Compound & $\begin{array}{c}\text { Mass } \\
\%\end{array}$ & Cation & K \\
\hline \hline C K & 0.277 & 5.55 & 0.10 & 14.46 & & & 1.1567 \\
\hline O K & 0.525 & 21.25 & 0.10 & 41.54 & & & 26.1851 \\
\hline Si K & 1.739 & 5.75 & 0.11 & 6.41 & & & 3.6824 \\
\hline Fe K & 6.398 & 65.36 & 0.24 & 36.60 & & & 67.0500 \\
\hline Zn K & 8.630 & 2.07 & 0.66 & 0.99 & & & & 1.9257 \\
\hline Total & & 100.00 & & 100.00 & & & \\
\hline
\end{tabular}

Dari hasil uji SEM menggambarkan bahwa unsur kimia Zn dan detail terhubungkan yang terbentuk pada Rz max, proses retak dan keropos. Kerusakan kombinasi dari thermal fatique dan retak dengan liquid metal embrittlement (LME) dibuktikan dari hasil uji SEM

C.Analisa Komposisi Kimia 
Giyanto, Penelitian kerusakan riser tube pada mesin LPDC dan upaya pencegahannya

Berdasarkan hasil pemeriksaan visual, dipandang perlu untuk melakukan pengujian analisa komposisi kimia sebagai berikut :

Tabel 1. Hasil uji komposisi kimia pada riser tube

\begin{tabular}{|c|c|c|c|}
\hline \multirow{2}{*}{\begin{tabular}{c}
\multirow{2}{*}{ KIMIA } \\
\cline { 2 - 3 }
\end{tabular}} & \multicolumn{2}{|c|}{ RESULT ( WT \% ) } & \multirow{2}{*}{ STANDAR } \\
\cline { 2 - 3 } & BAGIAN ATAS & BAGIAN BAWAH & \multirow{2}{*}{ IIS G5501 } \\
\hline \hline $\mathrm{C}$ & $>4.50$ & $>4.50$ & $3.2-2.5$ \\
\hline $\mathrm{Si}$ & 2.83 & 2.1 & $2.0-2.5$ \\
\hline $\mathrm{S}$ & $>0.180$ & $>0.180$ & 0.15 \\
\hline $\mathrm{P}$ & 0.106 & 0.125 & $0.4 \mathrm{Max}$ \\
\hline $\mathrm{Mn}$ & 0.824 & 0.629 & $0.6-0.8$ \\
\hline $\mathrm{Fe}$ & 77.5 & 86.1 & 93.2 \\
\hline $\mathrm{Cr}$ & 0.185 & 0.134 & \\
\hline $\mathrm{Ni}$ & 1.35 & 1.45 & \\
\hline $\mathrm{Mo}$ & 0.250 & 0.162 & \\
\hline $\mathrm{Cu}$ & 1.14 & 1.01 & \\
\hline $\mathrm{Al}$ & 0.0039 & 0.0010 & \\
\hline $\mathrm{V}$ & 0.180 & 0.144 & \\
\hline $\mathrm{Ti}$ & 0.0558 & 0.0418 & \\
\hline $\mathrm{Co}$ & $>0.200$ & $>0.188$ & \\
\hline $\mathrm{Nb}$ & 0.200 & 0.200 & \\
\hline $\mathrm{Zr}$ & 0.0503 & 0.0217 & \\
\hline $\mathrm{Pb}$ & 0.1240 & 0.0997 & \\
\hline
\end{tabular}

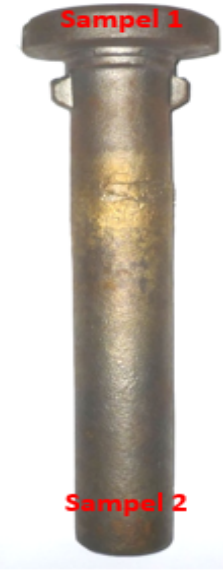

Dari analisa komposisi kimia Riser Tube kondisi bagian atas (sampel 1) dan bagian bawah (sampel 2) dapat disimpulkan bahwa :

1) Unsur karbon (C) pada Riser Tube sesuai dengan standar JIS G5501 2007 (3.2 - 3.5\%C), pada kondisi bagian atas $(>4.50 \% \mathrm{C})$ dan kondisi bagian bawah $(>4.50 \% \mathrm{C})$ memperlihatkan perbedaan komposisi karbon yang significant sehingga Riser Tube terpengaruh efek panas dengan berkurangnya sifat kekerasan, sifat tarik, elongasi, kekuatan impact namun mempercepat titik lebur.

2) Unsur silikon (Si) pada Riser Tube sesuai dengan standar JIS G5501 2007 (2.0-2.5\%Si), pada kondisi bagian atas $(2.83 \% \mathrm{Si})$ dan kondisi bagian bawah $(2.10 \% \mathrm{Si})$ untuk kondisi bagian atas lebih tinggi dibandingkan standart sehingga ketahanan material kurang handal dan menurunnya sifat mekanis logam dan kondisi bagian bawah sesuai dengan standar JIS G5501 ( yaitu $2.0-2.5 \% \mathrm{Si}$ ).

3) Unsur sulfur (S) pada Riser Tube sesuai dengan standar JIS G5501 2007 (0.15\%S) namun pada kondisi bagian atas $(>0.180 \% \mathrm{~S})$ dan kondisi bagian bawah $(>0.180 \% \mathrm{~S})$ lebih tinggi dari standart, dengan tingginya unsur sulfur (S) pada material sulfur maka akan mempengaruhi sifat mampu mesin dan sifat kekerasannya.

4) Unsur phosfor (P) pada Riser Tube sesuai dengan standar JIS G5501 2007 (0.4\%P max), kondisi bagian atas $(0.106 \% \mathrm{P})$ dan kondisi bagian bawah $(0.125 \% \mathrm{P})$ lebih rendah sehingga mempengaruhi terbentuknya fasa ferit dan meningkatkan ketahanan korosi dan oksidasi.

5) Unsur mangan (Mn) pada Riser Tube sesuai dengan standar JIS G5501 2007 (0.6 - 0.8\%Mn), pada kondisi bagian atas $(0.824 \% \mathrm{Mn})$ dan kondisi bagian bawah $(0.629 \% \mathrm{Mn})$ untuk bagian atas lebih tinggi sehingga material tahan pada temperatur tinggi namun elongasi turun dan kondisi bagian bawah sesuai dengan standar JIS G5501 ( yaitu $0.6-0.8 \% \mathrm{Mn}$ )

Unsur Besi (Fe) pada Riser Tube sesuai dengan standar JIS G5501 2007 (93.2\%Fe), pada kondisi bagian atas $(77.5 \% \mathrm{Fe})$ dan kondisi bagian bawah $(86.1 \% \mathrm{Fe})$ merupakan do minasi / material utama sehingga akan terpengaruh komposisinya jika unsur - unsur lainnya ( $\mathrm{Cr}, \mathrm{Ni}, \mathrm{Mo}, \mathrm{Cu}, \mathrm{Al}, \mathrm{V}, \mathrm{Ti}, \mathrm{Co}, \mathrm{Nb}, \mathrm{Zr}, \mathrm{Pb}$ ) berubah.

\section{d. Analisa Kekerasan}

Analisa kekerasan pada Riser Tube bagian dalam dimaksudkan untuk menganalisa perubahan kekerasan akibat panas yang diterima. Sampel uji kekerasan diambil masing-masing pada daerah dekarburisasi / kepala Riser Tube, daerah tengah kepala Riser Tube dan daerah yang terendah material brass ingot. Uji kekerasan tersebut menggunakan metode Hardness Vikers (ASTM SNI -19-0409-1989) dengan beban 5 Kgf, sudut indentor $136^{\circ}$ dan waktu uji 15 detik. 

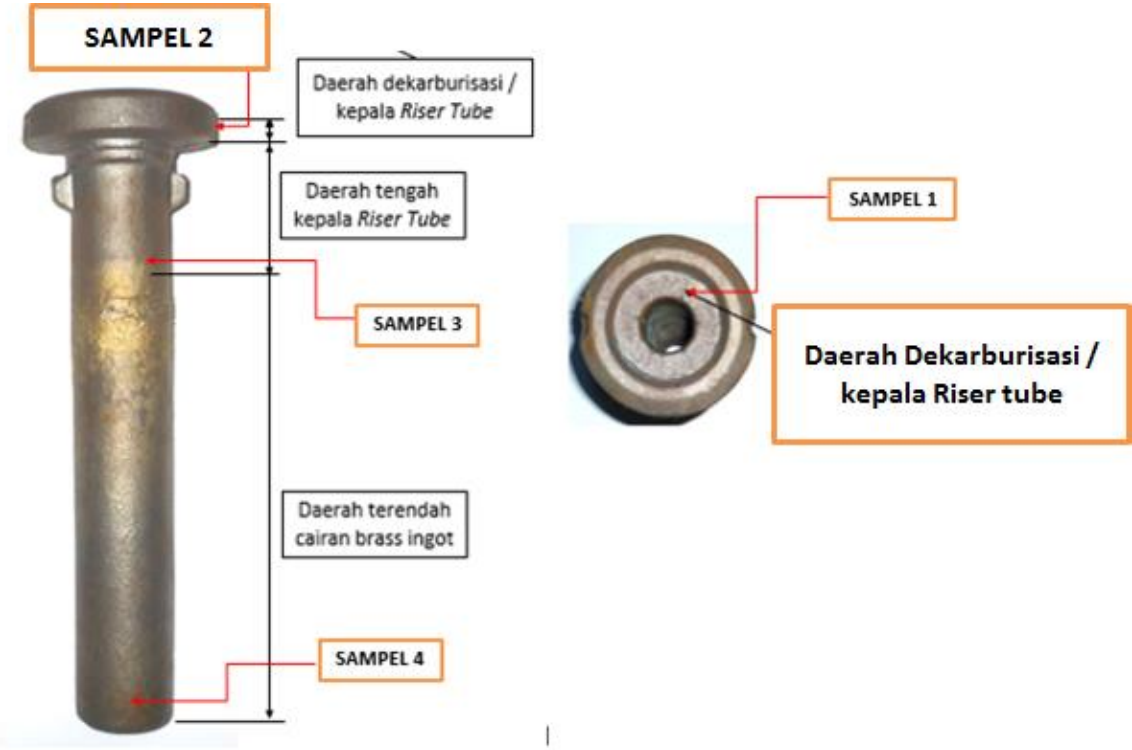

Gambar 11. Benda uji Riser Tube untuk uji kekerasan hardness Vickers

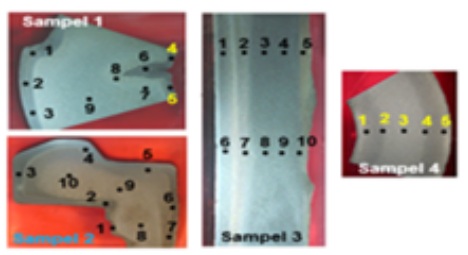

\begin{tabular}{|l|l|l|l|l|l|}
\hline \multirow{2}{*}{ NO. } & \multicolumn{4}{|l|}{ NILAI KEKERASAN, HV } & \multirow{2}{*}{ Standar } \\
\cline { 2 - 5 } & Sampel 1 & Sampel 2 & Sampel 3 & Sampel 4 & \\
\hline 1 & 86.3 & 109.4 & 167 & 183 & \\
\hline & & & & \\
\hline 2 & 78.8 & 96.5 & 210 & 306 \\
\hline 3 & 74.4 & 94.7 & 249 & 246 & \multirow{3}{*}{ ASTM G 3500 } \\
\hline 4 & 116.4 & 108.8 & 198 & 286 \\
\hline 5 & 115.0 & 86.7 & 86.7 & 257 & \\
\hline 6 & 105.6 & 144 & 218 & - & \\
\hline 7 & 143.5 & 175 & 227 & - \\
\hline 8 & 153 & 144 & 234 & - & \\
\hline 9 & 188 & 199 & 179 & - & \\
\hline 10 & - & 161 & 121 & - \\
\hline
\end{tabular}

Gambar 12. Hasil uji kekerasan hardness vikers

Hasil uji kekerasan dengan skala vikers (HV) adalah sebagai berikut :

- Nilai kekerasan pada daerah dekaburisasi anatara $74.4 \sim 108.8 \mathrm{HV}$

- Nilai kekerasan pada daerah tengah kepala Riser Tube antara $115 \sim 199$ HV.

- Nilai kekerasan pada daerah terendam liguid brass ingot antara $179 \sim 306 \mathrm{HV}$

\section{KESIMPULAN DAN SARAN}

Berdasarkan hasil analisa dan pembahasan pada BAB IV dapat diambil beberapa kesimpulan sebagai berikut:

1. Material Riser Tube terbuat dari grey iron casting sesuai dengan spesifikasi JIS Ferrous Materials dan Metallurgy I 2007 G5501 terdapat Pearlitic grey casting

2. Jenis kerusakan yang terjadi pada Riser Tube kemungkinan bisa disebabkan oleh efek kombinasi :

3. Thermal cyclis kemudian terjadi Thermal stress cyclis \& mengakibatkan terjadi Fatique crack

4. Melalui crack/retak cairan $\mathrm{Cu}+\mathrm{Zn}$ masuk atau penetrasi menjadi korosi suhu tinggi atau LME

5. Hasil struktur mikro menguji pada LME kemudian terjadi perubahan struktur fearlit menjadi ferrit dibuktikan berubah struktur tersebut dapat terjadi thermal fatique

6. Hasil SEM menguji unsur kimia Zn dan detail terhubungkan yang terbentuk pada Rx max, proses retak dan keropos. Kerusakan kombinasi dari thermal fatique dan retak dengan LME dibuktikan dengan hasil uji SEM 
- Perlu dilakukan pengkajian kembali secara lebih detail dalam pemilihan material, desain, pemasangan Riser Tube terhadap ketahanan panas.

- Perlu ditambahkan prosentase paduan (alloy) tertentu pada proses manufaktur (Pengecoran body Riser Tube) Zr, Cr, Mo dan Ni

\section{DAFTAR PUSTAKA}

1. Andrew KS Jardine, Albert H.C Tsang, Maintenance, Replacement and Reliability, CRC Press, 2006

2. Anrinal, Metalurgi fisik, Andi, Padang, Februari 2013

3. Christopher J, Mc Cauley, Machinery's Handbook, 29th Edition, 2012

4. $\quad$ Daryanto, Ilmu Metalurgy. Satu nusa, Bandung, Oktober 2010

5. D,N. Adnyana, Struktur dan Sifat Mekanis Material Logam, Diktat Mata Kuliah Program Pasca Sarjana (S2) ISTN Jakarta, 2003.

6. Ensiklopedia bebas, Besi tuang - Wikipedia bahasa indonesia, https://id.wikipedia.org/wiki/besi_tuang/

7. Jay Heizer, Barry Render, Operations Management, 2001

8. Japanes Standards Association, Ferrous Material \& Metalurgy, JIS Hanbook, Japan 2007

9. J.P. Holman, "Perpindahan Kalor” Erlangga, 1993

10. Jhon Moubray, Reliability Centered Maintenance, 2nd, Industrial Press Inc, 1997

11. KWC Enginering, LPDC and Maintenance. INDUGA Industrieofen and Giesserei-Anlagen GmbH \& Co., Germany, 2010

12. Kenji chijiiwa, Tata Surdia, Teknik pengecoran logam, Balai pustaka, Bandung, Nov. 1986

13. KARL-ERIC,T.,Steel and Its HeatTreatment, $2^{\text {nd }}$, Buffer Warth\&Co Boston,London 1994.

14. R. Widodo, Paduan $\mathrm{Cu} \& \mathrm{ZN}$ (Kuningan) HAPLI, 06 Januari 2012. https : //hapli.wordpress.com/non_ferro/paduan-cuzn-kuningan.

15. R.Widodo, Komposisi besi cor kelabu, HAPLI, 20 April 2012. https//hapli.wordpress.com/forumferro/komposisi-besi-cor-kelabu/

16. Stephen I Karsay, Ductile Iron II, Quebec Iron and Titanium Corporation, Canada 1997

17. The American Foundrymen's Society, Inc, Aluminium Casting Technology, Des Plaines, USA 1993 